\title{
Association between physical education, school-based physical activity, and academic performance: a systematic review \\ Asociación entre la educación física, la actividad física en la escuela, y el rendimiento académico: una revisión sistemática
}

\author{
*Adilson Marques, **Francisco Gómez, ***João Martins, ****Ricardo Catunda, ${ }^{* * * *}$ Hugo Sarmento

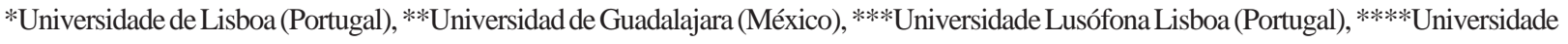 \\ Estadual do Ceará (Brasil), *****Universidade de Coimbra (Portugal)
}

\begin{abstract}
Background: The time allocation for physical education school-based physical activity is often replaced with other classes in an effort to increase children's academic performance. However, a growing body of literature suggests that physical activity either had no effect on academic performance or that it enhanced it. Objective: The purpose of this report is to perform a systematic review of the evidence on the associations between physical education and school-based physical activity, and academic performance. Design: Systematic review. Methods: Studies were identified through research of the PubMed, Sportdiscus, and Web of Science databases from 2000 through 2016. The titles and abstracts were screened for eligibility, the methodological quality of the studies was rated, and data was extracted. The main exposure was physical education or school-based physical activity. For the main outcome, studies had to report at least one academic performance measure. Results: A total of 12 articles met the inclusion criteria; four of them were cross-sectional, two longitudinal, two quasi-experimental and four interventional studies. Seven articles found a positive association between physical education or school-based physical activity and academic performance, four found no association and in one there was a positive association for $3^{\text {rd }}$ grade students and a negative association for $2^{\text {nd }}$ grade students. Conclusion: In general, results of the review support that physical education or school-based physical activity is positively associated with academic performance in children.
\end{abstract}

Keywords: academic achievement, physical activity, cognition.

Resumen. Introducción: La asignación de tiempo para la actividad física o la educación física en escuelas a menudo se sustituye con otras clases, en un esfuerzo para incrementar el rendimiento académico de los niños. Sin embargo, un número creciente de estudios sugieren que la actividad física o no tiene algún efecto sobre la mejora del rendimiento académico. Objetivo: El objetivo de este manuscrito es realizar una revisión sistemática de la evidencia sobre la asociación entre la educación física y la actividad física en la escuela, y el rendimiento académico. Diseño: Revisión sistemática. Métodos: Se identificaron estudios a partir de búsquedas en las bases de datos PubMed, Sportdiscus y Web of Science de 2000 a 2016 . Se proyectaron los títulos y los resúmenes de elegibilidad, se calificó la calidad metodológica de los estudios y se extrajeron los datos. Las principales exposiciones fueron la educación física o la actividad física en la escuela durante el horario escolar. Para el resultado principal, los estudios debían informar al menos una medida de rendimiento académico. Resultados: Un total de 12 artículos cumplieron los criterios de inclusión, cuatro de ellos eran de la sección transversal, dos longitudinales, dos cuasi-experimental y cuatro estudios de intervención. Siete artículos encontraron una asociación positiva entre la educación física o la actividad física en las escuelas y el rendimiento académico, en cuatro no se encontró ninguna asociación y en uno se encontró una asociación positiva para los estudiantes de $3^{\text {er }}$ grado y una asociación negativa para los estudiantes de $2^{\text {do }}$ grado. Conclusión: En general, los resultados de la revisión apoyan que la educación física o la actividad física en la escuela se asocia positivamente con el rendimiento académico en los niños.

Palabra clave: rendimiento académico, actividad física, la cognición.

\section{Introduction}

The health benefits of physical activity in children are well documented (Hardman \& Stensel, 2009), and the practice of physical activity on a regular basis is recommended (WHO, 2010). Strategies to enhanced children's physical activity have been developed and physical education is recognized as a place that contributes to increase children's physical activity levels (European Union, 2008; USDHHS, 2008; WHO, 2010). In fact, physical education and school-based physical activity provide an opportunity for children to be active during school (Pate et al., 2006; Strong et al., 2005), and have many benefits, which included an increase physical activity and an improvement in physical fitness and muscular endurance (Calahorro-Canada, Torres-Luque, LopezFernandez, \& Carnero, 2016; Sallis et al., 1997).

Although the well-known benefits of physical activity in children's health and the importance of the physical education in increasing the physical activity levels, in several countries physical education time allocation has been diminishing (UNESCO, 2014). The reducing time for physical education is mostly due to the substantial pressures placed on children, parents, and school administrators to improve academic performance, because there is a perception that time spent on non-academic courses, such as physical education, has a negative impact on the children's academic performance(Lindner, 2002). Therefore, the time allocation for physical education and time for physical activity in school settings are being replaced with other classes in an effort to increase the children's academic performance.

Fecha recepción: 06-06-16. Fecha de aceptación: 15-11-16 Adilson Marques

amarques@fmh.ulisboa.pt
In spite of this trend, no clear evidence indicates that academic performance improves if children's physical activity opportunities are cut short. Agrowing body of literature has examined the association of physical activity with cognition and academic performance in children. Among these studies, mixed results have emerged, suggesting that physical activity either had no effect on academic performance or that it enhances it.(Donnelly et al., 2016; Esteban-Cornejo, Tejero-Gonzalez, Sallis, \& Veiga, 2015; Singh, Uijtdewilligen, Twisk, van Mechelen, \& Chinapaw, 2012).

Considering that schools provide a unique opportunity to influence children's physical activity, because the children population has to attend to school compulsory, it is important to examine the relationship between physical education and school-based physical activity, which is physical activity at school settings, and academic performance (CDC, 2010). Therefore, to extend the understanding of this association, the purpose of this report is to synthesize the scientific literature that has examined the association between physical education and school-based physical activity, and academic performance. The results of the review can provide a tool to help education and health professionals with program and policy efforts.

\section{Methods}

The present systematic review was performed in accordance with the Preferred Reporting Items for Systematic Reviews and MetaAnalysis (PRISMA) guidelines (Moher, Liberati, Tetzlaff, Altman, \& Group, 2009), and the association of physical activity and academic performance protocol for systematic reviews (Alvarez-Bueno et al., 2016). 


\section{Selection of the literature}

During October 2016, a comprehensive search of three databases of literature (PubMed, Sportdiscus, Web of science) from 2000 through 2016, using search terms suitable to each specific database. Search terms were defined through discussion among the research team. The search terms were as follows: «physical activity» OR «physical education» OR sport OR «athletic participation» OR exercise AND «academic achievement» $\mathrm{OR}$ «academic performance» $\mathrm{OR}$ «academic attainment» $\mathrm{OR}$ «academic skills» $\mathrm{OR}$ «academic ability» $\mathrm{OR}$ «performance at school» $\mathrm{OR}$ «cognitive performance». The same terms were used in each database to identify potential articles with abstracts for review. Titles and abstracts were assessed for eligibility for inclusion in the review by two authors, coding as “yes”, "no”, or "maybe». Duplicate entries were removed and potential relevant articles were retrieved for a full read. Authors reviewed the full text of potential articles, and decisions to include or exclude studies in the review were made by consensus.

\section{Inclusion criteria}

A predetermined set of inclusion criteria was used to select articles for this systematic review. Each study had to meet the following criteria: (1) being published from 2000 to October 2016 (temporal criteria); (2) cross sectional, longitudinal or interventional study design (study design criterion); (3) school-aged children and adolescents aged 6 to 18 years; or students from primary, elementary and high school when participants' age was not mentioned (participants criterion); (4) it aimed to determine the association of physical education or school-based physical activity and academic performance (relationship criteria); (5) the outcomes included students' school grade or a standardized test or measure of academic performance (outcome measure criterion); (6) it was an article published in English, Portuguese or Spanish (language criterion).

\section{Data extraction}

The data extraction was based on PRISMA statement (Moher et al., 2009). A data extraction template was developed to extract the main details of the eligible study in terms of author, title, country, design, sample size, physical education or school based physical activity measurement, academic performance assessment, and results about the relationship between physical education and school based physical activity and academic performance. Two researchers carried out the search process. A single researcher examined every title and abstract to identify a potentially relevant paper for review. In case of uncertainty, a second researcher checked the selection process.

\section{Methodological quality assessment}

Two researchers rated the articles in overall quality. Discrepancies were resolved by consensus. Study quality was assessed using checklist criteria from the Quality Assessment Tool for Quantitative Studies (National Collaborating Centre for Methods and Tools, 2008). The checklist is comprised of 19 items, assessing 8 key methodological domains (sections): selection bias, study design, confounders, blinding, data collection methods, withdrawals and dropouts, intervention integrity, and analyses. Each article's methodology was classified as strong, moderate or weak.

\section{Synthesis of results}

Significant heterogeneity existed within study for several study parameters. These parameters included the following: participant characteristics, academic performance measures, and physical education or school based physical activity assessment methods. The details for each study, including design, measures, participant characteristics and sample size, study quality and results, are presented in a consistent manner.
Records identified through

database searching $(\mathrm{n}=593)$ PubMed $(\mathrm{n}=151)$ Sportdiscus $(\mathrm{n}=67)$

Web of science $(\mathrm{n}=375)$

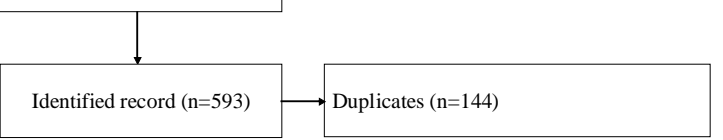

reening

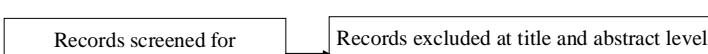
title/abstract $(\mathrm{n}=449)$ $(n=371)$

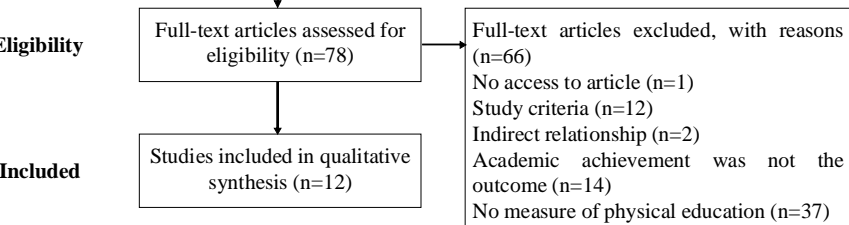

ure 1. Flow diagram of studies

\section{Results}

\section{Study selection}

The systematic literature research yielded a total of 593 potential relevant records. After excluding the duplicates $(\mathrm{n}=144)$, the title and abstract of 449 articles were screened. A total of 371 articles were rejected at title and abstract level. Subsequently, the full-text of 78 articles was obtained and reviewed. Of these 78 articles, 66 were excluded. Therefore, 12 articles passed the eligibility criteria and were included in the systematic review. The flow of citations through the systematic review process is shown in figure 1.

\section{General study characteristics}

From the twelve included articles, four were of cross-sectional design (Bradley, Keane, \& Crawford, 2013; Coe, Pivarnik, Womack, Reeves, \& Malina, 2006; Kim \& So, 2012; Simms, Bock, \& Hackett, 2014), two were longitudinal (Carlson etal., 2008; Stevens, To, Stevenson, \& Lochbaum, 2008), two were quasi experimental(Mullender-Wijnsma et al., 2015; Reed et al., 2010), and four were interventions (Ahamed et al., 2007; Ardoy et al., 2014; Käll, Nilsson, \& Lindén, 2014; Resaland et al., 2016). Most studies took place in the United States (Carlson et al., 2008; Coe et al., 2006; Reed et al., 2010; Simms et al., 2014; Stevens et al., 2008) and the others were from Canada (Ahamed et al., 2007), Ireland (Bradley et al., 2013), the Netherland (Mullender-Wijnsma et al., 2015), Norway (Resaland et al., 2016), South Korea (Kim \& So, 2012), Spain (Ardoy et al., 2014), and Sweden (Käll et al., 2014). The sample size ranged from 67 participants to 75066 participants, aged 6 through 18 years. One study was considered to be of weak methodological quality (Bradley et al., 2013), five of moderate quality (Kim \& So, 2012; Mullender-Wijnsma et al., 2015; Reed et al., 2010; Simms et al., 2014; Stevens et al., 2008) and the other six of the strong quality (Ahamed et al., 2007; Ardoy et al., 2014; Carlson et al., 2008; Coe et al., 2006; Käll et al., 2014; Resaland et al., 2016).

Physical education, school based physical activity and academic performancemeasurements

In four studies students, teachers or school principal reported the number of physical education classes per week (Carlson et al., 2008; Kim \& So, 2012; Simms et al., 2014; Stevens et al., 2008) as a measure of physical education. In one study the school-based physical activity was assessed based on school sport participation (Bradley et al., 2013), in another one school-based physical activity was estimated using the three day physical activity recall and for physical education classes the System for Observing Fitness Instruction Time was used (SOFIT) (Coe et al., 2006). Three out of four intervention studies (Ardoy et al., 


\begin{tabular}{|c|c|c|c|c|}
\hline Source & $\begin{array}{l}\text { Study design, study sample } \\
\text { characteristics (country, age range/mean, } \\
\text { grade, sex, n), and methodological } \\
\text { quality }\end{array}$ & Outcome measured & PA, PE measure or experiment description & Main results \\
\hline Bradley et al., 2013 & $\begin{array}{l}\text { Cross-sectional } \\
\text { Ireland, } 17-18 \text { years, boys, } \mathrm{n}=402 \\
\text { Weak quality }\end{array}$ & $\begin{array}{l}\text { Leaving Certificate results } \\
\text { (the Irish State School } \\
\text { Examination) }\end{array}$ & $\begin{array}{l}\text { The school sports participation was assessed } \\
\text { according to } 4 \text { categories: rugby, rowing, soccer, } \\
\text { and no sport. }\end{array}$ & $\begin{array}{l}(+) \text { Participating in any sport at school was related } \\
\text { with better average Leaving Certificate score } \\
\text { compared to points from students not participating in } \\
\text { sport }(431.5 \text { points vs. } 406.1) \text {. Participating in } \\
\text { individual sports confers a further benefit to academic } \\
\text { results. }\end{array}$ \\
\hline Coe et al., 2006 & $\begin{array}{l}\text { Cross-sectional } \\
\text { USA, } 11.5 \text { years, } 6^{\text {th }} \text { grade, boys and girls, } \\
\mathrm{n}=214 \\
\text { Strong quality }\end{array}$ & $\begin{array}{l}\text { Grades for each student } \\
\text { (mathematics, science, } \\
\text { English, and world } \\
\text { studies) and the Terra } \\
\text { Nova standardized } \\
\text { test scores. }\end{array}$ & $\begin{array}{l}\text { PA was estimated using the 3-d PA recall } \\
\text { (3DPAR). For PE classes was used the System } \\
\text { for Observing Fitness Instruction Time } \\
\text { (SOFIT). } \\
\text { Students were enrolled in PE during one semester } \\
\text { and the other semester they were enrolled in an } \\
\text { alternative exploratory class (i.e., arts and } \\
\text { computer classes). }\end{array}$ & $\begin{array}{l}\text { (0) AP (combined scores of all disciplines) was not } \\
\text { affected by the timing of PE class enrolment. The } \\
\text { Terra Nova standardized test scores, were also not } \\
\text { affected by PE class enrolment. }\end{array}$ \\
\hline Kim \& So, 2012 & $\begin{array}{l}\text { Cross-section } \\
\text { South Korea, } 15.1 \text { years, middle school } 1^{\text {st }} \\
\text { grade to high school } 3^{\text {rd }} \text { grade, boys and } \\
\text { girls, } n=75066 \\
\text { Moderate quality }\end{array}$ & $\begin{array}{l}\text { Students were asked how } \\
\text { their average school } \\
\text { performance had been in } \\
\text { the last } 12 \text { months. The } \\
\text { response options were } \\
\text { very good, good, average, } \\
\text { poor, and very poor. }\end{array}$ & $\begin{array}{l}\text { Students reported the number of PE classes per } \\
\text { week in school. Responses options were no PE } \\
\text { class, once per week, twice per week, and =3 } \\
\text { times/week. }\end{array}$ & $\begin{array}{l}(+) \text { Attending }=3 \text { PE classes/week was positively } \\
\text { correlated with school performance. Attending }<3 \text { PE } \\
\text { classes/week increase } 12.5 \% \text { good AP, } 14.7 \% \text { average } \\
\text { AP, } 14.6 \% \text { poor AP, and } 19.1 \% \text { very poor AP, as } \\
\text { compared to very good AP. }\end{array}$ \\
\hline Simms et al., 2014 & $\begin{array}{l}\text { Cross-sectional } \\
\text { USA, 5th grade, boys and girls, } \mathrm{n}=10120 \\
\text { Moderate quality }\end{array}$ & $\begin{array}{l}\text { Children's AP was } \\
\text { measure in reading, } \\
\text { mathematics, and science } \\
\text { standardized tests. }\end{array}$ & $\begin{array}{l}\text { Teachers reported the typical participation in PE } \\
\text { for students in their classroom (i.e. } 0=\text { 'none'; } 1 \\
=\text { 'less than once a week'; } 2 \text { = 'once or twice a } \\
\text { week'; } 3 \text { = 'three or four times per week'; or } 4 \text { = } \\
\text { 'daily'). These teachers also reported how many } \\
\text { minutes the children in their classroom typically } \\
\text { participated in PE each day. }\end{array}$ & $\begin{array}{l}\text { (+) PE and AP were positively associated. However, } \\
\text { effect sizes indicated that this relationship was } \\
\text { relatively modest. }\end{array}$ \\
\hline Carlson et al., 2008 & $\begin{array}{l}\text { Longitudinal ( } 5 \text { years of follow up) } \\
\text { USA, from kindergarten to } 5^{\text {th }} \text { grade, boys } \\
\text { and girls, } n=5316 \\
\text { Strong quality }\end{array}$ & $\begin{array}{l}\text { Mathematics and reading } \\
\text { tests were applied. }\end{array}$ & $\begin{array}{l}\text { Classroom teachers reported the number of times } \\
\text { during the week (never, }<1,1 \text { or } 2,3 \text { or } 4 \text {, or } \\
\text { daily) and minutes per day (do not participate, } 1- \\
15,16-30,31-60 \text {, or }>60 \text { ) that students } \\
\text { participated in physical education. }\end{array}$ & $\begin{array}{l}\text { (+) Girls with the highest exposure to PE ( } 70-300 \\
\text { min/week) versus the lowest exposure ( } 0-35 \\
\text { minutes/week) exhibited a small AP benefit for } \\
\text { mathematics and reading. } \\
\text { (0) No association was observed between PE and AP } \\
\text { among boys. }\end{array}$ \\
\hline Stevens et al., 2008 & $\begin{array}{l}\text { Longitudinal ( } 5 \text { years of follow up) } \\
\text { USA, } 1^{\text {st }}, 3^{\text {rd }} \text { and } 5^{\text {th }} \text { grades, boys and girls, } \\
\mathrm{N}=3256 \\
\text { Moderate quality }\end{array}$ & $\begin{array}{l}\text { A latent construct of } \\
\text { mathematics and reading } \\
\text { achievement was created } \\
\text { utilizing the participants, } \\
\text { standardized mathematics } \\
\text { scores from third and fifth } \\
\text { grade school years. }\end{array}$ & $\begin{array}{l}\text { The latent construct of PE was assessed using one } \\
\text { variable collected at spring of kindergarten, 1st } \\
\text { grade, 3rd grade. School administrators were } \\
\text { asked how many times/week do children usually } \\
\text { have PE. Responses options were never, less than } \\
\text { once a week, 1-2 times/week, for 3-4 times/week, } \\
\text { and daily. }\end{array}$ & $\begin{array}{l}\text { (0) PE participation was not significantly related to } \\
\text { academic achievement. }\end{array}$ \\
\hline $\begin{array}{l}\text { Mullender-Wijnsma, } \\
\text { al., } 2015\end{array}$ & $\begin{array}{l}\text { A quasi-experimental design } \\
\text { The Netherland, } 8.1 \text { years, } 2^{\text {nd }} \text { and } 3^{\text {rd }} \\
\text { grades, boys and girls, } \mathrm{n}=228 \\
\text { Moderate quality }\end{array}$ & $\begin{array}{l}\text { Children were pretested } \\
\text { and post tested on } \\
\text { mathematics and reading. }\end{array}$ & $\begin{array}{l}\text { Six classes participated in the intervention } \\
(\mathrm{n}=58+56) \text { and other } 6 \text { classes formed the control } \\
\text { group }(\mathrm{n}=62+52) \text {. The intervention group } \\
\text { participated in physically active academic lessons } \\
\text { and the control group in regular classroom } \\
\text { lessons. Students attended active classes } 3 \text { times a } \\
\text { week, for } 21 \text { weeks. The intensity of the active } \\
\text { lessons was determined by heart rate } \\
\text { measurements. }\end{array}$ & $\begin{array}{l}(+) \text { The } 3^{\text {rd }} \text { grade children in the intervention group } \\
\text { scored significantly higher on both mathematics and } \\
\text { reading in comparison with the third-grade children in } \\
\text { the control group. } \\
\text { (-) The } 2^{\text {nd }} \text { grade children in the intervention group } \\
\text { scored significantly lower on mathematics in } \\
\text { comparison with the 2nd grade children in the control } \\
\text { group }\end{array}$ \\
\hline Reed et al., 2010 & $\begin{array}{l}\text { A quasi-experimental design } \\
\text { USA, } 9-11 \text { years, } 3^{\text {rd }} \text { grade, boys and girls, } \\
\mathrm{n}=155 \\
\text { Moderate quality }\end{array}$ & $\begin{array}{l}\text { Palmetto Achievement } \\
\text { Challenge Tests (PACT). } \\
\text { The Standard Progressive } \\
\text { Matrices was apply to } \\
\text { asses fluid intelligence. }\end{array}$ & $\begin{array}{l}\text { A random sample of } 3^{\text {rd }} \text { grade students } \\
\text { participated in the study. Three classrooms ( } \mathrm{n}= \\
\text { 80) were randomly assigned to the experimental } \\
\text { group and other } 3 \text { as ( } \mathrm{n}=75 \text { ) as control. The } \\
\text { experimental group integrated PA (e.g. running, } \\
\text { hopping, walking) into their core curricula } \\
\text { approximately } 30 \text { min/day, } 3 \text { days a week, for } 3 \\
\text { months. PA was assessed with pedometers and } \\
\text { with Previous Day Physical Activity Recall }\end{array}$ & $\begin{array}{l}+ \text { Children in the experimental group performed } \\
\text { significantly better on social studies academic } \\
\text { achievement test. Experimental group also had } \\
\text { received higher scores on the language, math and } \\
\text { science achievements tests, but were not statistically } \\
\text { significant compared with control group children. }\end{array}$ \\
\hline Ahamed et al., 2007 & $\begin{array}{l}\text { Intervention (16-month cluster RCT) } \\
\text { Canada, } 10.2 \text { y, } 4-5 \text { grades, boys and girls, } \\
\mathrm{n}=287 \\
\text { Strong quality }\end{array}$ & $\begin{array}{l}\text { Canadian Achievement } \\
\text { Test }\end{array}$ & $\begin{array}{l}\text { PAQ-C. Trained research assistants administered } \\
\text { the questionnaire three times during the school } \\
\text { year. }\end{array}$ & $\begin{array}{l}\text { (0) Additional } 10-15 \text { min of school time devoted to } \\
\text { PA did not compromise AP. }\end{array}$ \\
\hline Ardoy et al., 2014 & $\begin{array}{l}\text { Intervention (4-month RCT) } \\
\text { Spain, } 13.0 \text { years, boys and girls, } \mathrm{n}=67 \\
\text { Strong quality }\end{array}$ & $\begin{array}{l}\text { School grades in } \\
\text { mathematics and language }\end{array}$ & $\begin{array}{l}\text { Adolescents in the control group received } 55 \text { min } \\
\text { sessions twice per week. Adolescents in the } \\
\text { experimental group } 1 \text { had } 4 \text { PE sessions per week. } \\
\text { Adolescents in the experimental group } 2 \text { received } \\
\text { four PE sessions per week of high intensity. }\end{array}$ & $\begin{array}{l}(+) \text { Increasing the number and intensity of PE sessions } \\
\text { per week had a positive effect on academic } \\
\text { performance. }\end{array}$ \\
\hline Kall et al., 2014 & $\begin{array}{l}\text { Intervention } \\
\text { Sweden, } 5^{\text {th }} \text { grade, boys and girls, } \mathrm{n}=408 \\
\text { Strong quality }\end{array}$ & School grades & $\begin{array}{l}\text { Students had additional PA sessions ( } 30-45 \mathrm{~min}) \\
\text { twice a week in addition to the } 2 \text { hours of } \\
\text { curricular PE. The activities were designed to be } \\
\text { engaging, enjoyable, health promoting, and non- } \\
\text { competitive. These extra hours of PA were } \\
\text { scheduled and mandatory. The PA sessions were } \\
\text { planned and introduced by professional staff } \\
\text { members from the local sports club, from the } \\
\text { spring semester of } 2004 \text { onward. }\end{array}$ & $\begin{array}{l}\text { (+) School-based PA intervention program designed to } \\
\text { make students more physically active during the } \\
\text { school day significantly improved the children's } \\
\text { academic achievement. }\end{array}$ \\
\hline Resaland et al., 2016 & $\begin{array}{l}\text { Intervention (7-month RCT) } \\
\text { Norway, } 10.2 \text { years, } 5^{\text {th }} \text { grade, boys and } \\
\text { girls, } \mathrm{n}=1129 \\
\text { Strong quality }\end{array}$ & $\begin{array}{l}\text { Standardized Norwegian } \\
\text { national tests. }\end{array}$ & $\begin{array}{l}\text { Children from } 57 \text { elementary schools were } \\
\text { cluster-randomized by school either to the } \\
\text { intervention or to the control group. The children } \\
\text { in the } 28 \text { intervention schools participated in a PA } \\
\text { intervention consisting of three components: } 1) \\
90 \text { min/week of active educational lessons; } 2) 5 \\
\text { min/day of PA breaks during classroom lessons; } \\
\text { 3) } 10 \text { min/day PA homework. AP in numeracy, } \\
\text { reading and English were measured using } \\
\text { standardized Norwegian national tests. Physical } \\
\text { activity was measured objectively by } \\
\text { accelerometers. }\end{array}$ & $\begin{array}{l}\text { (0) It was not observed any significant effect of the } \\
\text { intervention on numeracy, reading, English or the } \\
\text { academic composite score. However, the intervention } \\
\text { significantly affected numeracy in children in the } \\
\text { lowest tertile of the numeracy score at baseline. }\end{array}$ \\
\hline \multicolumn{5}{|c|}{$\begin{array}{l}\text { RCT, randomized controlled trial; PA, physical activity; PE, physical education; AP, academic performance } \\
\text { (+) The symbol means that in general there is a positive correlation/association between school-based physical activity, physical education and academic performance. } \\
\text { (-) The symbol means that in general there is a negative correlation/association between school-based physical activity, physical education and academic performance. } \\
\text { (0) The symbol means that in general there is no correlation/association between school-based physical activity, physical education and academic performance. }\end{array}$} \\
\hline
\end{tabular}

2014; Käll et al., 2014; Resaland et al., 2016) did not measure the physical education or the school-based physical activity but increased the amount of physical education or physical activity classes offered within the school setting. In one intervention study and one quasi- experimental study the school-based physical activity was assessed by questionnaire (Ahamed et al., 2007; Reed et al., 2010). For the last quasi-experimental study, students from experimental groups had more physical active lessons and physical activity was measured by heart 
rate monitors (Mullender-Wijnsma et al., 2015).

The academic performance took into account a variety of disciplines (e.g. mathematics, language, science, and world studies). Three studies used school grades (Ardoy et al., 2014; Coe et al., 2006; Käll et al., 2014), three used achievement tests (Ahamed et al., 2007; Carlson et al., 2008; Mullender-Wijnsma et al., 2015), four used standardized tests (Bradley et al., 2013; Reed et al., 2010; Resaland et al., 2016; Simms et al., 2014), one used the students' average school performance (Kim \& So, 2012), and one used a latent construct of mathematics and reading achievement (Stevens et al., 2008).

\section{Principal findings}

The studies' characteristics and results are presented in table 1.

Results from the four cross-sectional studies generally support beneficial relationships between physical education or school-based physical activity and academic performance, with significant positive relationships being reported in three studies (Bradley et al., 2013; Kim \& So, 2012; Simms et al., 2014). Students that participated in schoolbased physical activity had better academic performance than those who did not participate in sports (Bradley et al., 2013). Based on this study's results, individual sports might confer further benefits to academic performance. Although this study used a big sample and a standardized test to assessed academic performance, it is a study of weak methodological quality. In the other two studies (Kim \& So, 2012; Simms et al., 2014), of moderate methodological quality, having more classes of physical education per week was positively correlated with academic performance. In one cross-sectional study a non-significant trend for a positive relationship was described(Coeetal., 2006).Although the results from this study were not significant it is noteworthy that the academic performance (combined scores of all disciplines) was not affected by the timing of physical education class enrolment.

Two longitudinal studies met the inclusion criteria and had sample sizes of 5316 and 3256 (Carlson et al., 2008; Stevens et al., 2008). The children were followed for 5 years. The results of these studies were inconsistent with regard to the relationship between physical education and academic performance. In one of these studies (Carlson et al., 2008) girls with the highest exposure to physical education (70-300 min/ week), versus the lowest exposure (0-35 minutes/week), showed benefits to their academic performance in mathematics and reading. However, the effect of the relationship was small, and no association was observed between physical education and academic performance among boys. In the other study (Stevens et al., 2008), physical education participation was not significantly related to academic performance.

In both quasi-experimental studies, of moderate methodological quality, in general they reported a significant and positive association between physical education and academic performance (MullenderWijnsma et al., 2015; Reed et al., 2010). In one study children from an experimental group performed significantly better on social studies; and also had higher scores on the language, mathematics and science, but were not statistically significant compared with the control group children (Reed et al., 2010). The other study results were apparently contradicted, because the third-grade grade children in the intervention group scored significantly higher on both mathematics and reading in comparison to the third-grade children in the control group, but the second-grade children in the intervention group scored significantly lower on mathematics in comparison to the second-grade children in the control group.

All intervention studies were of strong methodological quality, and three of them used a cluster randomized controlled trial design (Ahamed et al., 2007; Ardoy et al., 2014; Resaland et al., 2016). Two of the four intervention studies observed a significant beneficial effect of physical education or school-based physical activity on academic performance (Ardoy et al., 2014; Käll et al., 2014). Increasing the number and intensity of physical education sessions per week had a positive effect on academic performance (Ardoy et al., 2014), and two additional physical activity sessions designed to be engaging, enjoyable, health promoting, and noncompetitive improved the children's academic performance (Käll et al., 2014). In the other two intervention studies no significant effect of the intervention was observed on the academic performance (Ahamed et al., 2007; Resaland et al., 2016). Ten to fifteen-minutes of class time devoted to physical activity (Ahamed et al., 2007), ninety-minutes per week of active educational lessons, and five-minutes per day of physical activity breaks during classroom lessons (Resaland et al., 2016) did not increase academic performance, but did not compromised it either.

\section{Discussion}

The current review systematically reviewed 12 studies that used several study designs, including cross-sectional, longitudinal, quasiexperimental and intervention to address the question whether physical education or school-based physical activity is related with students' academic performance. The review summarizes all studies from 2000 to 2016 that met the defined criteria, regardless of study characteristics. In general, results from these studies suggest that physical education or school-based physical activity is positively related to academic performance.

From cross-sectional studies, the relation between physical education or school-based physical activity and academic performance seems to be positive. Two studies reported the number of physical education classes per week (Kim \& So, 2012; Simms et al., 2014). Although the effect sizes indicated that the relationship was relatively modest, increasing the number of physical education classes per week is thought to be beneficial to academic performance. These results of cross-sectional studies are reinforced by the results of the longitudinal (Carlson et al., 2008) and intervention (Ardoy et al., 2014) studies, in which the increasing number and intensity of physical education sessions per week had a positive effect on academic performance.

The positive observed association between the number of physical education sessions and academic performance is particularly important, because a reducing of physical education time allocation has been observed (UNESCO, 2014), and the argument to support this decision is mostly based on the fact that reducing physical education and increasing the other disciplines' allocation time will improve the students' academic performance. Although some reviewed studies did not show a significant association, the results from some cross-sectional (Coe et al., 2006), longitudinal (Stevens et al., 2008), and intervention (Ahamed et al., 2007; Resaland et al., 2016) studies indicated that physical education and school-based physical activity was not significantly related to academic achievement, and dedicating approximately 10 additional minutes of daily school physical activity, children's academic performance was not compromised. It means that physical education and school-based physical activity have a positive effect or do not have any deleterious effect on students' academic performance.

In a comprehensive revision of the association between schoolbased physical activity, including physical education, and academic performance (CDC, 2010), it was observed that physical activity either leads to a positive result or to no change in academic performance. The studies analysed also suggest that increased time spent in physical education is not likely to detract from academic performance even when less time is devoted to subjects other than physical education. Even physical activity breaks during standard classroom instruction seems to have favourable associations with attention, concentration, academic behaviours and academic achievement, as also observed in one intervention study of strong methodological quality (Ahamed et al., 2007). These observations are in agreement with a previous study prior to 2000 that examined the effects of a two-year health-related school physical education program on standardized academic performance scores (project SPARK) (Sallis et al., 1999). The program consisted of two intervention groups receiving twenty seven to forty four-minute additional physical education per week, compared to the control group. It was observed that spending more time in physical education did not have harmful effects on standardized academic performance test in elementary school. Furthermore, there was some evidence that a twoyear health related physical education had significant favourable effects on academic performance. 
This study has some limitations that have to be mentioned. This review focuses only on physical education and school-based physical activity. Although these activities can provide a general basis for the physical activity habits of children, they do not cover the complete range of physical activities in which children can participate. Therefore, the study results can be biases because some children could be very active outside school and less active in a school setting. Studies were not ranked or weighted, consequently, findings from studies with weaker designs and smaller sample sizes were given no less importance than findings from studies with more rigorous research designs and larger sample sizes. Nonetheless, the assessment of the methodological quality helped to partially minimize these discrepancies. Finally, the study results are difficult to interpret and compare, because of the several methodologies used and outcomes measured.

The strength of this review came from the extensive literature search using defined inclusion criteria to make advanced comparisons of the findings of full-text articles which passed the eligibility criteria. Moreover, this review took into account and systematically reviewed studies according to different study designs, and different methods of assessing physical education and physical activity in a school setting.

\section{Conclusion}

In conclusion, this study's results support evidence of a positive relationship of physical education or school-based physical activity with academic performance. In eight of twelve studies, with different study designs, it was observed that physical education or school-based physical activity have a positive effect on students' academic performance. On the other hand, there is no evidence that increasing time of physical education or school-based physical activity had deleterious effect on students' academic performance. Considering that education to foster academic performance takes place normally in sedentary environments, children spend an amount of time sitting in classrooms receiving instructions. This traditional view contributes to the reduction of physical activity at school. However, because physical education and school-based physical activity may affect positively learning and academic performance, and may impact positively on many other important outcomes (e.g. health and quality of life; physical, social and affective benefits), there is a need to increase physical activity time at school. The increase of physical activity will contribute to improve academic performance and, naturally, will be important to enhance the children's physical activity levels, which is so important for health.

\section{References}

Ahamed, Y., Macdonald, H., Reed, K., Naylor, P. J., Liu-Ambrose, T., \& McKay, H. (2007). School-based physical activity does not compromise children's academic performance. Med Sci Sports Exerc, 39(2), 371-376.

Alvarez-Bueno, C., Pesce, C., Cavero-Redondo, I., Sanchez-Lopez, M., PardoGuijarro, M. J., \& Martinez-Vizcaino, V. (2016). Association of physical activity with cognition, metacognition and academic performance in children and adolescents: a protocol for systematic review and meta-analysis. BMJOpen, 6(6), e011065.

Ardoy, D. N., Fernández-Rodríguez, J. M., Jiménez-Pavón, D., Castillo, R., Ruiz, J.R., \& Ortega, F. B. (2014).A Physical Education trial improves adolescents' cognitive performance and academic achievement: the EDUFIT study. Scandinavian Journal of Medicine \& Science in Sports, 24(1), e52-e61.

Bradley, J., Keane, F., \& Crawford, S. (2013). School Sport and Academic Achievement. Journal of School Health, 83(1), 8-13.

Calahorro-Canada, F., Torres-Luque, G., Lopez-Fernandez, I., \& Carnero, E. A (2016). Is physical education an effective way to increase physical activity in children with lower cardiorespiratory fitness? Scandinavian Journal of Medicine and Science in Sports.

Carlson, S. A., Fulton, J. E., Lee, S. M., Maynard, L. M., Brown, D. R., Kohl Iii, H.W., \& Dietz, W.H. (2008). Physical Education andAcademic Achievement in Elementary School: Data From the Early Childhood Longitudinal Study. American Journal of Public Health, 98(4), 721-727.

CDC. (2010). The association between school-based physical activity, including physical education, and academic performance.Atlanta, GA:U.S. Department of Health and Human Services.
Coe, D. P., Pivarnik, J. M., Womack, C. J., Reeves, M. J., \& Malina, R. M. (2006). Effect of physical education and activity levels on academic achievement in children. Med Sci Sports Exerc, 38(8), 1515-1519.

Donnelly, J. E., Hillman, C. H., Castelli, D., Etnier, J. L., Lee, S., Tomporowski, P., ... Szabo-Reed, A. N. (2016). Physical activity, fitness, cognitive function, and academic achievement in children: a systematic review. Medicine and Science in Sports and Exercise, 48(6), 1197-1222.

Esteban-Cornejo, I., Tejero-Gonzalez, C. M., Sallis, J. F., \& Veiga, O. L. (2015). Physical activity and cognition in adolescents: Asystematic review. Journal of Science and Medicine in Sport, 18(5), 534-539.

European Union. (2008). EU physical activity guidelines recommended policy actions in support of health-enhancing physical activity. Brussels: European Union.

Hardman, A., \& Stensel, D. (2009). Physical activity and health. The evidence explained. Oxon: Routledge.

Käll, L. B., Nilsson, M., \& Lindén, T. (2014). The impact of a physical activity intervention program on academic achievement in a Swedish elementary school setting. Journal of School Health, 84(8), 473-480.

Kim, S. Y., \& So, W. Y. (2012). The relationship between school performance and thenumber of physical education classes attended by korean adolescent students. Journal of Sports Science and Medicine, 11(2), 226-230.

Lindner, K. J. (2002). The physical activity participation-academic performance relationship revisited: Perceived and actual performance and the effect of banding (academic tracking). Pediatric Exercise Science, 14(2), 155-169.

Moher, D., Liberati, A., Tetzlaff, J., Altman, D. G., \& Group, P. (2009). Preferred reporting items for systematic reviews andmeta-analyses: thePRISMA statement. Annals of Internal Medicine, 151(4), 264-269, W264.

Mullender-Wijnsma, M. J., Hartman, E., de Greeff, J. W., Bosker, R. J., Doolaard, S., \& Visscher, C. (2015). Improving Academic Performance of School-Age Children by Physical Activity in the Classroom: 1-Year Program Evaluation. Journal of School Health, 85(6), 365-371.

National Collaborating Centre for Methods and Tools. (2008). Quality Assessment Tool for Quantitative Studies Method. Retrieved 1 July 2016, 2016, from http://www.nccmt.ca/resources/search/14

Pate, R. R., Davis, M. G., Robinson, T. N., Stone, E. J., McKenzie, T. L., \& Young, J. C. (2006). Promoting physical activity in children and youth: a leadership role for schools: a scientific statement from the American Heart Association Council on Nutrition, Physical Activity, and Metabolism (Physical Activity Committee) in collaboration with the Councils on Cardiovascular Disease in the Young and Cardiovascular Nursing. Circulation, 114(11), 12141224.

Reed, J.A., Einstein, G., Hahn, E., Hooker, S. P., Gross, V. P., \& Kravitz, J. (2010). Examining the impact of integrating physical activity on fluid intelligence and academic performance in an elementary school setting: apreliminary investigation. Journal of Physical Activity \& Health, 7(3), 343-351.

Resaland, G. K., Aadland, E., Moe, V. F., Aadland, K. N., Skrede, T., Stavnsbo, M., ... Anderssen, S. A. (2016). Effects of physical activity on schoolchildren's academic performance: The Active Smarter Kids (ASK) cluster-randomized controlled trial. Preventive Medicine, 91, 322-328.

Sallis, J. F., McKenzie, T. L., Alcaraz, J. E., Kolody, B., Faucette, N., \& Hovell, M. F. (1997). The effects of a 2-year physical education program (SPARK) on physical activity and fitness in elementary school students. Sports, Play and Active Recreation for Kids. American Journal of Public Health, 87(8), 13281334.

Sallis, J. F., McKenzie, T. L., Kolody, B., Lewis, M., Marshall, S., \& Rosengard, P.(1999). Effects of health-related physical education on academic achievement: project SPARK. Research Quarterly for Exercise and Sport, 70(2), 127-134.

Simms, K., Bock, S., \& Hackett, L. (2014). Do the duration and frequency of physical education predict academic achievement, self-concept, social skills, food consumption, and body mass index? Health Education Journal, 73(2), 166-178.

Singh, A., Uijtdewilligen, L., Twisk, J. W., van Mechelen, W., \& Chinapaw, M. J. (2012). Physical activity and performance at school: a systematic review of the literature including a methodological quality assessment. Archives of Pediatrics and Adolescent Medicine, 166(1), 49-55.

Stevens, T. A., To, Y., Stevenson, S. J., \& Lochbaum, M. R. (2008). The importance of physical activity and physical education in the prediction of academic achievement. Journal of Sport Behavior, 31(4), 368-388.

Strong, W., Malina, R., Blimkie, C., Daniels, S., Dishman, R., Gutin, B., . . Trudeau, F. (2005). Evidence based physical activity for school-age youth. The Journal of Pediatrics, 146, 732-737.

UNESCO. (2014). World-wide survey of school physical education. Report 2013. Paris: United Nations Educational, Scientific and Cultural Organization.

USDHHS. (2008). 2008 physical activity guidelines for Americans. Be active, healthy, and happy! Washington DC: USDHHS.

WHO. (2010). Global recommendations on physical activity for health. Geneva: World Health Organization. 